\title{
Investigation of Seasonal Influenza and Pneumococcal Vaccination Status in Chronic Kidney Failure Patients Undergoing Hemodialysis: A Survey Study
}

\section{Hemodiyalize Giren Kronik Böbrek Yetmezliği Hastalarında Mevsimsel İnfluenza ve Pnömokok Aşılanma Durumunun Değerlendirilmesi: Bir Anket Çalışması}

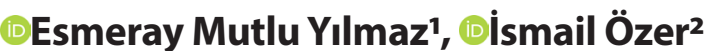 \\ 'University of Health Sciences, Samsun Training and Research Hospital, Samsun, Turkey \\ 2VM Medical Park Hospital, Samsun, Turkey
}

\begin{abstract}
Aim: Respiratory tract infections due to influenza virus are more mortal in hemodialysis patients than in the healthy population. These patients should be provided with influenza vaccination every year. In this study; the frequency of influenza vaccination in hemodialysis patients in our region and the factors affecting it were investigated.
\end{abstract}

Material and Method: A total of 239 patients who had undergone hemodialysis for at least one year were asked the prepared questionnaires. The obtained data were analyzed in SPSS 20 program.

Results: The rate of seasonal influenza vaccination of the patients was $87 \%$. Vaccination rates were found to be significantly higher in patients with a duration of hemodialysis longer than five years and those who were vaccinated in the last year (respectively $p=0.02, p=0.016$ ). The rate of pneumococcal vaccination in those vaccinated against influenza and the rate of vaccination in the families of these patients were also found to be significantly higher $(p<0.01)$.

Conclusion: In this study, it was found that influenza vaccination rates were high in patients undergoing hemodialysis in our region. The reason for this is that the influenza vaccine is provided free of charge to those with chronic diseases every year by the Ministry of Health in our country.

Keywords: Influenza vaccination, chronic kidney disease, hemodialysis
Öz

Amaç: Influenza virüsüne bağlı solunum yolu infeksiyonları hemodiyaliz hastalarında sağlıklı popülasyona göre daha mortal seyretmektedir. Bu hastaların her yıl influenza aşısı olmaları sağlanmalıdır. Bu çalışmada; hastanemizde hemodiyalize giren KBY hastalarında influenza aşısı yaptırma sıkığı ve buna etki eden faktörler araştırılmıştır.

Gereç ve Yöntem: En az bir yıldır hemodiyalize giren toplam 239 hastaya hazırlanan anket soruları soruldu. Elde edilen veriler SPSS 20 programında analiz edildi.

Bulgular: Hastaların mevsimsel influenza aşısı olma oranı \%87 idi. Hemodiyalize girme süresi beş yıldan uzun olanlarda ve geçen yıl da aşı olanlarda aşılanma oranları anlamlı derece yüksek bulundu (sırasıyla $p=0,02, p=0,016$ ). İnfluenza aşısı olanlarda pnömokok aşısı olma oranı ve bu hastaların ailelerinde aşı olma oranı da anlamlı oranda yüksek bulundu $(p<0,01)$.

Sonuç: Bu çalışmada bölgemizde hemodiyalize giren hastalarda influenza aşılama oranlarının yüksek olduğu bulunmuştur. Bunun sebebi olarak ülkemizde sağlık bakanlığı tarafınca influenza aşısının kronik hastalığı olanlara her yıl ücretsiz sağlanmasının büyük payı vardır.

Anahtar Kelimeler: Grip aşısı, kronik böbrek hastalığı, hemodiyaliz

Corresponding (illetişim): Esmeray MUTLU YILMAZ, S.B.U. Samsun Training and Research Hospital, Department of Clinical Microbiology and Infectious Diseases, Samsun, Turkey

E-mail (E-posta): emutlu55@gmail.com

Received (Geliș Tarihi): 14.08.2021Ａccepted (Kabul Tarihi): 21.10 .2021 


\section{INTRODUCTION}

Influenza virus is one of the common agents of viral respiratory tract infections. Hemodialysis patients have a higher risk for influenza-related illness and death compared to the healthy population. Hospitalization for pneumonia and sepsis is higher in this patient group than in the general population. ${ }^{[1,2]}$ In particular, a 10-fold increased annual risk of mortality has been reported for pneumonia and 100 -fold for sepsis. ${ }^{[3]}$ Vaccination is the most effective and inexpensive way to prevent the flu. ${ }^{[4]}$ For this reason, it is recommended that patients with CKD and the households living with them to be vaccinated each year before the start of the flu season. ${ }^{[5]}$ The influenza vaccine is safe and effective in all age groups over 6 months. Vaccination is important especially in all people over 50 years of age, in all groups where influenza may cause serious complications such as chronic pulmonary (including asthma) or cardiovascular (except isolated hypertension), renal, hepatic or metabolic disorders (includin diabetes mellitus). ${ }^{[6]}$

Influenza vaccine is also safe in CRF patients. The Advisory Committee on Immunization Practices (ACIP) has recommended trivalent inactivated influenza vaccine to patients with end-stage renal disease for more than 40 years. ${ }^{[7]}$ It was first shown in 1982 that influenza vaccine is safe in patients with chronic renal failure and that the vaccine does not cause deterioration in renal functions. ${ }^{[8]}$ However, exacerbations of autoimmune diseases may occur after influenza vaccination.

Vaccination rates were found to be higher in those with chronic lung, heart and kidney disease than in the healthy population. ${ }^{[9]}$ In this study; In this study, it was aimed to investigate the frequency of influenza vaccination in CRF patients undergoing hemodialysis in our region and the factors affecting it, and to reveal the situation in our country.

\section{MATERIAL AND METHOD}

In this prospective study, questionnaire questions were asked to patients undergoing hemodialysis in Samsun Training and Research Hospital in 2015. Patients undergoing hemodialysis for more than a year were included in the study, newly diagnosed cases were excluded. All patients signed the informed consent form. During the face-to-face interviews with the patients, demographic characteristics including age, gender, how many years they had undergone hemodialysis, their status of getting influenza and pneumococcal vaccines and the reasons for not having them were asked. Vaccination experiences and perspectives on vaccination were evaluated by asking questions about the subjective experiences affecting vaccination behavior as well as complication experiences. There was no flu epidemic during the study. The obtained data were recorded in the SPSS 20 program and statistical analysis was performed. Descriptive analysis was used to calculate frequencies and ratios, and the chi-square test was used to investigate the level of correlation between variables. A $p$ value less than 0.05 was considered statistically significant.
This study was approved by the Non-interventional Clinical Research Ethics Committee of Samsun Training and Research Hospital (Date: 09.06.2021, Decision No: 2021/11/12) and our study was carried out in accordance with Principles of the Helsinki Declaration.

\section{RESULTS}

Of the 239 patients participating in the study, $120(50 \%)$ were female and the mean age was $56+13$ years (minimum 25 -maximum 85 years). Of the patients, 207 (87\%) had received seasonal influenza vaccination. It was determined that there was no difference between the genders of being vaccinated against influenza ( $85 \%$ in women, $88 \%$ in men) ( $p>0.05$ ).

When the patients were divided into two groups as under 65 years old and 65 years old and over; there was no significant difference between the two groups in terms of vaccination rate ( $86 \%$ in the young group, $92 \%$ in the elderly group) ( $p>0.05)$. The mean duration of hemodialysis was 4 years (minimum 1-maximum 18 years). When those who have been on hemodialysis for four years or less and those who have been on hemodialysis for five years or more are compared; vaccination rates were found to increase proportionally with the duration of hemodialysis entry $(p=0.02)$. None of the patients reported any side effects related to the vaccine.

The rate of seasonal flu vaccination in the families of the patients was found to be $48 \%$. While this rate was $52 \%$ in the families of those who had the flu vaccine, it was $23 \%$ in the families of those who didn't have the flu vaccine $(p<0.01)$.

Pneumococcal vaccination rate was $40 \%(n=96) .45 \%$ of the patients who had flu vaccine and $6.5 \%$ of those who didn't stated that they had pneumococcal vaccine $(p<0.01)$.

It was determined that the patients were largely aware (92.5\%) of the $\mathrm{H} 1 \mathrm{~N} 1$ epidemic in 2009. There was no difference in the rates of influenza vaccination between those who heard of this epidemic and those who did not $(87 \%$ and $89 \%$, respectively, $\mathrm{p}=0.81$ ). The data obtained when comparing those with and without the flu vaccine are shown in Table 1.

When the reasons for not being vaccinated were examined; The most common reason was the disbelief in the efficacy of the vaccine. Other reasons are given in Table 2.

\begin{tabular}{lcc} 
Table 2. Reasons for not getting vaccinated for flu vaccine & \\
\hline Answers & Number (n) & (\%) \\
\hline I do not believe the vaccine is effective & 19 & 60 \\
I don't trust the vaccine & 7 & 22 \\
I didn't know I had to get vaccinated & 4 & 12 \\
I couldn't get the vaccine & 1 & 3 \\
I already had the flu & 1 & 3 \\
Total & 32 & 100 \\
\hline
\end{tabular}




\begin{tabular}{|c|c|c|c|c|c|}
\hline & \multicolumn{2}{|c|}{$\begin{array}{l}\text { Who have the flu } \\
\text { vaccine }(n=207)\end{array}$} & \multicolumn{2}{|c|}{$\begin{array}{l}\text { Who don't have the } \\
\text { flu vaccine }(n=32)\end{array}$} & \multirow{2}{*}{ p } \\
\hline & Number & (\%) & Number & $(\%)$ & \\
\hline \multicolumn{5}{|l|}{ Age } & $>0.05$ \\
\hline$<65$ & 153 & 85.5 & 26 & 14.5 & \\
\hline$\geq 65$ & 55 & 92 & 5 & 8 & \\
\hline \multicolumn{5}{|c|}{ Hemodialysis time } & 0.01 \\
\hline$\leq 4$ years & 122 & 83 & 25 & 17 & \\
\hline$\geq 5$ years & 86 & 93.5 & 6 & 6.5 & \\
\hline \multicolumn{5}{|c|}{ Get the flu vaccine last year } & $<0.01$ \\
\hline Yes & 186 & 96 & 8 & 4 & \\
\hline No & 22 & 49 & 23 & 51 & \\
\hline \multicolumn{5}{|c|}{ Have you ever had the flu vaccine? } & $<0.01$ \\
\hline Yes & 175 & 96 & 7 & 4 & \\
\hline No & 33 & 58 & 24 & 42 & \\
\hline \multicolumn{5}{|c|}{ Have you had the pneumonia vaccine? } & $<0.01$ \\
\hline Yes & 94 & 98 & 2 & 2 & \\
\hline No & 114 & 80 & 29 & 20 & \\
\hline \multicolumn{5}{|c|}{ Do your family members get the flu vaccine? } & $<0.01$ \\
\hline Yes & 108 & 94 & 7 & 6 & \\
\hline No & 100 & 81 & 24 & 19 & \\
\hline
\end{tabular}

\section{DISCUSSION}

This study is the first questionnaire study to measure the approach to influenza vaccine in hemodialysis patients in Turkey. In our country, influenza vaccination rate was $22 \%$ and pneumococcal vaccination rate was $6 \%$ in patients over 65 years of age. ${ }^{[10]}$ In our study, it was found that the annual seasonal influenza and pneumococcal vaccination rates were higher in hemodialysis patients compared to the general population.

The risk of pulmonary infection-related mortality in patients with end-stage renal disease undergoing hemodialysis is 1416 times higher than in the general population. ${ }^{[3]}$ It has been shown that morbidities such as total hospitalization time, ICU stay, pneumonia/flu, septicemia/bacteremia/viremia, respiratory failure and heart disease are seen at a lower rate with influenza vaccination in this patient group, and that allcause mortality is reduced by $50 \%$ with vaccination. ${ }^{[1]}$

In our study, the rate of influenza vaccination was found to be high. This rate is above the rates specified in the world. In a study in which cases diagnosed with CRF for the first time were included, the influenza vaccination rate was $1 \%$ in 1998 , and it was found to be $38 \%$ in $2009 .{ }^{[1]}$ Again, in a study conducted between 1998 and 2001, the influenza vaccination rate for each year was found to be below $50 \% \cdot{ }^{[12]}$ In a survey study of 133 patients, the rate of getting the flu vaccine was $67 \%$, while the rate of updating the vaccine regularly for the last two years was $50 \% .{ }^{[13]}$ In a study conducted in Austria, the influenza vaccination rate of hemodialysis patients was found to be $22 \%{ }^{[14]}$ The reason for our high rate may be that we included patients who had been on hemodialysis for more than a year. These results show that the awareness of hemodialysis patients in our country is good.
Since 2011, seasonal influenza vaccines are provided free of charge to all people over the age of 65 , those with chronic lung diseases such as asthma and chronic obstructive pulmonary disease, cardiovascular diseases such as hypertension, chronic metabolic diseases such as diabetes (Type 1 and 2), and chronic kidney diseases. We think that the free access to the vaccine has an important contribution to our high vaccination rates.

The efficacy of inactivated influenza vaccine in healthy elderly is $70-90 \%$. It has been shown that the risk of serious complications decreased by $60 \%$ and the mortality rate by $80 \%$ with influenza vaccination in healthy elderly people[4] In a 4-year prospective observational study conducted in the elderly population from 1998 to 2002, it was shown that the influenza vaccination rate was $48 \%$, and the hospitalization rates were significantly lower in the unvaccinated group compared to the vaccinated group (59\% vs. $40 \%$, respectively). ${ }^{[15]}$ In this study, although there was no relationship between age and influenza vaccination, the rate of vaccination was found to be higher in elderly patients.

In this study, it was observed that the rate of influenza vaccination increased by years. it can be concluded that the first vaccine is important in terms of raising awareness. The training given in the first vaccination is an important step in gaining the awareness that the vaccination should be repeated every year. Also, as the duration of hemodialysis increases, the increase in vaccination also shows that awareness has increased over the years.

Pneumococcal infections are more common in patients with CRF than in healthy individuals. The Advisory Committee on Immunization Practices (ACIP) recommends the polysaccharide pneumococcal vaccine to all dialysis patients aged 2 years and older. ${ }^{[16]}$ In this study a positive correlation was found between being vaccinated against pneumococcus and being vaccinated against influenza. Being vaccinated against the flu also affects susceptibility to pneumococcal vaccine. When patients start hemodialysis, they should be informed that they should get annual influenza vaccine. With the annual influenza vaccine, the awareness of the patients to receive the polysaccharide pneumococcal vaccine every five years is also increased.

The rate of having the flu vaccine in the families of those who had the flu vaccine was found to be higher. It is possible to evaluate this in two ways. Persons caring for patients may be vaccinated to protect themselves and therefore their patients. Or we can say that the presence of someone in the family who has received training in vaccination also increases social awareness and sensitivity.

There was no relationship between being aware of the H1N1 flu epidemic and getting the flu vaccine. In our study, flu vaccination rates of hemodialysis patients were found to be quite high. The reason why vaccination rates are similar between those who are aware of the H1N1 epidemic and those who aren't can be attributed to the fact that these patients are already trained in flu vaccination. 
Influenza vaccine is generally well tolerated. The most common side effects are local reactions with erythema and induration at the injection site. Systemic reactions, including acute febrile disease, hypersensitivity reactions, and Guillian Barre syndrome are rare. ${ }^{[17]}$ There were no serious side effects related to the vaccine in the patients participating in this study.

However, patients with renal failure may show a decreased immune response to the vaccine compared to the general population due to their immunosuppressed state. It has been shown that transplanted, CAPD and hemodialysis patients do not reach high levels of protective antibody titers as healthy individuals. ${ }^{[18]}$ While the 4 -fold antibody response after vaccination is $64 \%$ in healthy individuals, this response can be seen only in $50 \%$ of hemodialysis patients. ${ }^{[19,20]}$ Despite this, it is known that the vaccine can induce immunity in a significant proportion of patients. ${ }^{[4]}$ With the influenza vaccine, hospitalization and mortality are significantly reduced in hemodialysis patients. ${ }^{[11,21]}$

This study was carried out in Samsun is an important health center for both its own population and patients coming from the surrounding provinces in the Central Black Sea region. For this reason, we think that our data gives a good idea about the general population. It can also be considered as a limiting aspect of the study.

\section{CONCLUSION}

As a result; In this study, influenza vaccination rates were found to be high in patients undergoing hemodialysis in our region. The most important reason for this is that access to the vaccine is free in our country. It is important to raise awareness of the patients about the efficacy, safety and necessity of influenza vaccine and to have them vaccinated annually.

\section{ETHICAL DECLARATIONS}

Ethics Committee Approval: This study was approved by the Non-interventional Clinical Research Ethics Committee of Samsun Training and Research Hospital (Date: 09.06.2021, Decision No: 2021/11/12).

Informed Consent: All patients signed the free and informed consent form.

Referee Evaluation Process: Externally peer-reviewed.

Conflict of Interest Statement: The authors have no conflicts of interest to declare.

Financial Disclosure: The authors declared that this study has received no financial support.

Author Contributions: All of the authors declare that they have all participated in the design, execution, and analysis of the paper, and that they have approved the final version.

\section{REFERENCES}

1. Allon M, Depner TA, Radeva M, et al. Impact of dialysis dose and membrane on infection-related hospitalization and death: results of the HEMO Study. J Am Soc Nephrol 2003;14(7):1863-70.

2. Guo H, Liu J, Collins AJ, Foley RN. Pneumonia in incident dialysis patients--the United States Renal Data System. Nephrol Dial Transplant 2008;23(2):680-6.

3. Sarnak MJ, Jaber BL. Mortality caused by sepsis in patients with endstage renal disease compared with the general population. Kidney Int 2000;58(4):1758-64.

4. Mastalerz-Migas A, Gwiazda E, BrydakLB. Effectiveness of influenza vaccine in patients on hemodialysis--a review. Med Sci Monit 2013;19:1013-8.

5. Control CfD, Prevention: Prevention and control of influenza; recommendations of the Advisory Committee on Immunization Practices (ACIP). Prevention and control of influenza: recommendations of the Advisory 2003;52:16-24.

6. Fiore $A E$, Uyeki TM, Broder K, et al. Prevention and control of influenza with vaccines: recommendations of the Advisory Committee on Immunization Practices (ACIP), 2010.

7. Eickhoff TC. Immunization against Influenza: Rationale and Recommendations. J Infect Dis 1971;123(4):446-54.

8. Nikoskelainen J, Vaananen P, Forsstrom J, Kasanen A. Influenza vaccination in patients with chronic renal failure. Scand J Infect Dis 1982;14(4):245-51.

9. Mutlu H, Coskun F, Sargin M. The incidence and awareness of vaccination among people aged 65 and over applied to a family medicine outpatient clinic. Ankara Med J 2018; 1:1-13.

10. Yılmaz T, Şencan İ, Yılmaz TE, et al. The Assessment of Knowledge Levels and Practices of Family Physicians Practicing in Family Health Centers in Ankara with Regard to Well Child Follow-up. Ankara Med J 2018; 18(3):312-21.

11. Wang IK, Lin CL, Lin PC, et al. Effectiveness of influenza vaccination in patients with end-stage renal disease receiving hemodialysis: a population-based study. PLoS One 2013;8(3):e58317.

12. McGrath LJ, Kshirsagar AV, Cole SR, et al. Influenza vaccine effectiveness in patients on hemodialysis: an analysis of a natural experiment. Arch Intern Med 2012;172(7):548-54.

13. Wilmore SM, Philip KE, Cambiano V, et al. Influenza and pneumococcal vaccinations in dialysis patients in a London district general hospital. Clin Kidney J 2014;7(1):27-32.

14. Eder M, Omic H, Gorges J, et al. Influenza vaccination uptake and factors influencing vaccination decision among patients with chronic kidney or liver disease. PloS one 2021;16(4):e0249785.

15. Landi F, Onder G, Cesari M, et al. In a prospective observational study, influenza vaccination prevented hospitalization among older home care patients. J Clin Epidemiol 2006; 59(10):1072-7.

16. Grohskopf LA, Bresee JS, Cox N, Shimabukuro TT Prevention and control of influenza with vaccines: recommendations of the Advisory Committee on Immunization Practices (ACIP)--United States, 2012-13 influenza season. 2012.

17. Duggal T, Segal P, Shah M, Carter-Monroe N, Manoharan P, Geetha D. Antineutrophil cytoplasmic antibody vasculitis associated with influenza vaccination. Am J Nephrol 2013;38(2):174-8.

18. Cavdar C, Sayan M, Sifil A, et al. The comparison of antibody response to influenza vaccination in continuous ambulatory peritoneal dialysis, hemodialysis and renal transplantation patients. Scand J Urol Nephrol 2003;37(1):71-6.

19. Koşan C. Aşilarin Kronik Diyaliz Hastalarında Kullanımı. MJAU 2002;34:259.

20. Jordan MC, Rousseau WE, Tegtmeier GE, Noble GR, Muth RG, Chin TD. Immunogenicity of inactivated influenza virus vaccine in chronic renal failure. Ann Intern Med 1973;79(6):790-4.

21. Kunisaki KM, Janoff EN: Influenza in immunosuppressed populations: a review of infection frequency, morbidity, mortality, and vaccine responses. Lancet Infect Dis 2009;9(8):493-504. 